DOI https://doi.org/10.30525/978-9934-26-073-5-2-76

\title{
ФОРМУВАННЯ ІНШОМОВНОЇ КОМПЕТЕНТНОСТІ ЯК ВАЖЛИВИЙ КОМПОНЕНТ НАВЧАННЯ В СФЕРІ ЮРИСПРУДЕНЦЇ̈
}

\author{
Тернова О. I. \\ старший викладач кафедри сучасних європейських мов \\ Київського національного торговельно-економічного університету
}

Коротка Н. В.

дочент кафедри іноземних мов за професійним спрямуванням та гуманітарних дисичилін

Київського державного університету інфраструктури та технологій

\begin{abstract}
Підколесна Л. А.
старший викладач кафедри сучасних європейських мов

Київського національного торговельно-економічного університету
\end{abstract}

м. Київ, Україна

Сучасна державна політика в сфері освіти спрямована на поліпшення якості освоєння програм, розроблених в рамках опанування іноземної мови за професійним спрямуванням. Така обставина означає, що вимоги, які пред’являються до рівня володіння іноземною мовою сьогоднішніми студентами, стали значно вище і жорсткіше. Це пов'язано 3 тим, що зростає роль іншомовного спілкування, в суспільстві виникає потреба в спеціалістах, які дійсно володіють іноземною мовою, мають високий рівень усної та писемної грамотності. В умовах сучасності професія юриста дуже популярна, але ще більш популярним $є$ фахівець, який володіє іноземною мовою в області своєї професійної діяльності. Так, фахівці-юристи, які володіють іноземною мовою, безумовно, зможуть отримати високі посади в міжнародних компаніях, і як наслідок, отримуватимуть більш високу заробітну плату, у порівнянні 3 тими фахівцями, які навіть при високому професіоналізмі, не мають іншомовної компетентності. Таким чином, необхідною складовою цього процесу є комунікативна компетентність фахівця.

Поняття «компетенція» походить від латинського слова compete, яке означає «підходити, відповідати». У загальному сенсі воно означає відповідність пропонованим вимогам, встановленим критеріям i стандартам в певних областях діяльності і при вирішенні певного типу 
завдань, володіння необхідними активними знаннями, здатність впевнено домагатися результатів і володіти ситуацією [4 с. 20-26]. Під комунікативною компетентністю науковці розуміють здатність встановлювати й підтримувати необхідні контакти 3 іншими людьми. Проблема комунікативної компетентності розглядалася в працях І. Баскакової , Ф. Бацевич, Ю. Жукова, Є. Ільїна , О. Корніяки, С. Куранової, С. Максименка, А. Матюшкіна, В. Москаленко, Л. ОрбанЛембрик та інших авторів. Науковці виокремлюють здебільшого такі складові комунікативної компетентності: готовність і уміння будувати контакти $з$ людьми; внутрішні засоби регуляції комунікативних дій; знання, уміння i навички конструктивного спілкування; здатність орієнтуватися у різноманітних ситуаціях спілкування та віднаходити способи їх розв'язання; здатність ефективно взаємодіяти 3 професійним оточенням тощо.

Викликає інтерес погляд I. Зязюна на компетентність, яку він вважає першоосновою професійності. На перше місце тут вчений ставить комплексність знань, а саме: вміння синтезувати матеріал, аналізувати ситуації спілкування, осмислювати суть явищ, обирати засоби взаємодії [2. c. 25-28].

Мета доповіді - визначити роль іноземної мови в професійній діяльності майбутнього фахівця-юриста, довести, що формування іншомовної компетентності $\epsilon$ надзвичайно важливим компонентом навчання в сфері юриспруденції.

Сенс професійно-орієнтованого навчання іноземної мови полягає в його взаємозв'язку зі спеціальними дисциплінами для набуття додаткових професійних знань, і як результат, формування у студентів іншомовної компетентності в конкретних професійних, ділових, наукових сферах і ситуаціях з урахуванням особливостей професійної діяльності [3, с. 571].

Іноземну мову необхідно розглядати як компонент професійної підготовки юристів 3 початку іï вивчення у ВНЗ. На першому етапі, програма вивчення повинна мати чітко виражену професійну спрямованість і не містити вузькоспеціальних термінів. Зміст навчального матеріалу на старших курсах, навпаки, мусить включати в себе вузькогалузеву спрямованість [5, с. 245]. В ході формування іншомовної компетентності майбутніх юристів,необхідно мати на увазі, що сучасному фахівцеві необхідно мати рівень, який дозволив би йому спілкуватися з фахівцями 3 інших країн. Для цього, він повинен знати основи граматики та володіти значним обсягом лексики юридичної спрямованості. Адже за умови, що майбутній юрист буде володіти 
граматичним мінімумом, який охоплює основні правила морфології $\mathrm{i}$ синтаксису i дозволяє правильно розуміти іншомовний текст, але не володіє професійною лексикою, неможливо вільно відчувати себе при розмові 3 іншими фахівцями-юристами i не розгубитися при обговоренні будь-якої професійної ситуації. Тому важлива роль при іншомовній підготовці студентів-юристів надається засвоєнню професійної лексики [5, с. 24].

В процесі вивчення іноземної мови професійного спрямування, майбутнім юристам необхідно враховувати наступні складнощі текстів юридичного дискурсу:

- переважання стилістично нейтральних i книжкових слів; відсутність «зниженої» лексики, елементів просторіччя і жаргону, а також емоційних слів і зворотів (вигуків, слів зі зменшувальними i збільшувальними суфіксами, вигукувань і риторичних питань і т. п.);

- широке вживання професійної термінології (у випадку, що нас цікавить - юридичної: measure, application, capacity, claim);

- часте використання віддієслівних іменників (injunction, arbitration, bankruptcypetition, cancellation, limitation, omission);

- поширеність юридичних кліше, які, за правилами ділового стилю, зазвичай не заміняються відповідними дієсловами (to abandon an action, assess men to damage, to break an agreement, to break the law, to draw up a contract, in case of controversy)

- використання антонімів, так як закони відображають полярні інтереси - права і обов'язки громадян (plaintiff-defendant, sane-insane, action-inaction);

- вживання латинізмів (dejure, defacto, archive) [1, с. 117];

- використання дієслів i зворотів 3 пасивним значенням (the defendant's guiltis confirmed by the following circumstances);

- суворий та чіткий порядок слів у реченні:

a) підмет найчастіше стоїть на початку речення i, як правило, передує присудкові (the Contracting Parties agree and here by establish the Organization);

б) доповнення стоять після керуючого ними слова (Have resolved to combine our efforts to accomplish the seaim);

в) обставинні слова (прислівники) стоять по можливості ближче до слова, до якого вони відносяться за змістом (In consequence where of the ydo here by create the Organization);

г) ввідні слова і звороти зазвичай знаходяться на початку речення;

- кількісне переважання складних речень над простими; 
- широке вживання дієприкметникових і дієприслівникових оборотів, що надають мови лаконізм і динамічність [1, с. 118] (Have accordingly concluded this Convention; Have agreed as follows...; Have agreed to establish...; Have agreed to the present Charter; Here by agree...; Have agreed upon the following...).

Однією з головних особливостей зовнішнього мовного вираження думки законодавця є офіційність, документальність. Правовий текст «не описує події, факти, наукові поняття, почуття і переживання людей, не характеризує ставлення до певних осіб, явищ дійсності. Він не доводить, не пояснює, не переконує, а владою наказує суб'єктам права певну поведінку, формулює вимоги, загальнообов'язкові приписи [1, с. 119]. Графічні способи оформлення текстів правових актів, які сприяють підвищенню ïx інформативності, допомагають вирішенню проблем автоматизованої обробки правової інформації в сучасних умовах. Тексти діючих правових актів повинні бути лінгвістичним зразком мови і стилю.

Отже, у підсумку, зазначимо, що формування у майбутніх фахівцівюристів іншомовної компетентності $€$ надзвичайно важливим компонентом навчання юристів. Фахівці, які мають певні професійні навички, завжди будуть лідерами при виборі кандидата на певну посаду.

\section{Література:}

1. Алимов В.В. Юридический перевод: Практический курс. Английский язык: учеб. пособие. Москва: ЛЕНАНД, 2015. 160 с.

2. Зязюн I.А. Педагогічна майстерність: підручник. Київ . : Вища школа, 2004. 422 c.

3. Кочесокова М.К., Дортман С.Р. Роль иностранного языка в профессиональной деятельности юристов. «Форум молодых ученых». 2019. № 4(32). С. 571-575.

4. Мильруд Р.П. Компетентность в изучении языка. Иностранный язык в школе.2004. № 7. С. 20-26.

5. Протасова Н.А., Ессина И.Ю., Ефимова И.И., Семенова Э.В. Иностранный язык как компонент профессиональной подготовки специалиста-юриста. Вестник Саратовской государственной юридической академии.2015. № 5 (106). С. 243-248. 